Creative Commons User License: CC BY-NC-ND

Abstracted by: EBSCOhost, Electronic Journals Service (EJS),

Google Scholar, Journal Seek, Scientific Commons,

Food and Agricultural Organization (FAO), CABI and Scopus

http://eoi.citefactor.org/10.11226/v23i4
Journal of Agricultural Extension

Vol. 24 (1) January, 2020

ISSN(e): 24086851; ISSN(Print); 1119944X

http://journal.aesonnigeria.org

http://www.ajol.info/index.php/jae

Email: editorinchief@aesonnigeria.org

\title{
Social-Cognitive Factors Influencing Household Decisions to Grow Orange- Fleshed Sweet Potato in Uganda
}

https://dx.doi.org/10.4314/jae.v24i1.1

\section{Ndaula Sulaiman}

Department of Extension and Innovation Studies, College of Agricultural and Environmental Sciences, Makerere University, Box 7062, Kampala, Uganda. Email: ndaulasulah@gmail.com Tel: +256 779412686

\section{Sseguya Haroon}

International Institute of Tropical Agriculture, Regional Hub for Eastern Africa, Dar-es-Salaam, Tanzania. Email: h.sseguya@cgiar.org Tel: +255756975800

\section{Matsiko Frank}

Department of Extension and Innovation Studies, College of Agricultural and Environmental Sciences, Makerere University, Box 7062, Kampala, Uganda. Email: fbmatsiko@gmail.com Tel: +256753265642

\section{Abstract}

This study examined the role of social-cognitive factors in farmers' decisions to cultivate orange-fleshed sweetpotato as a food-based approach to alleviating vitamin A deficiency among rural households in Uganda. Cross-sectional survey data collected from 341 randomly selected household level decision-makers drawn from two rural districts in Uganda were analysed using hierarchical regression. Perceived capability and perceived social approval significantly predicted household decisions to grow orange-fleshed sweet potato ( $p \leq 0.001)$. Overall, decision-makers' subjective norms and control beliefs were found to be significant mediators $(p \leq 0.01)$ of the orange-fleshed sweet potato acceptance process. These results point to a cardinal role for processes that create supportive social and cognitive environments in promoting the cultivation of biofortified technologies such as orange-fleshed sweet potato.

Keywords: Orange-fleshed sweet potato, social approval, Uganda

\section{Introduction}

Vitamin A deficiency (VAD), a form of hidden hunger, is a major public health challenge in sub-Saharan Africa (HarvestPlus, 2016). In Uganda's case, 36\% of the pre-school children and $38 \%$ of the women of childbearing age are deficient in vitamin A (Wirth et al., 2017). Accordingly, bio-fortification-a relatively new strategy that mainly uses conventional breeding techniques to enrich the micronutrient content of targeted staples-is being promoted as a strategy that is well suited to address VAD challenges in rural areas (HarvestPlus, 2016).

For the three most widely promoted vitamin A bio-fortified crops in Uganda, (that is, orange-fleshed sweet potato (OFSP), orange cassava and orange maize), the fortification involves enrichment with B-carotene, a precursor for the vitamin (Low et al., 
Creative Commons User License: CC BY-NC-ND

Abstracted by: EBSCOhost, Electronic Journals Service (EJS),

Google Scholar, Journal Seek, Scientific Commons,

Food and Agricultural Organization (FAO), CABI and Scopus

http://eoi.citefactor.org/10.11226/v23i4
Journal of Agricultural Extension

Vol. 24 (1) January, 2020

ISSN(e): 24086851; ISSN(Print); 1119944X

http://journal.aesonnigeria.org

http://www.ajol.info/index.php/jae

Email: editorinchief@aesonnigeria.org

2017). Many OFSP varieties and delivery efforts have been implemented since the late 1990s, attracting diverse stakeholder support. Central to the associated promotional strategies is working with communities that already produce and consume selected crops as staples to progressively replace conventional varieties with bio-fortified ones (Asare-marfo et al., 2013).

It is argued, for example, that OFSP where eaten regularly provides $100 \%$ of the daily vitamin A needs and that a $500 \mathrm{~m}^{2}$ plot of OFSP is adequate for meeting the annual needs of the vitamin of a family of five (Low et al., 2017). Proponents of OFSP also maintain that it shares many attributes with the energy-dense white fleshed sweet potato which is popular for its short maturity period, staggered root maturation that allows gradual harvesting over several months, and easy access to the vegetative planting materials.

Even with the above benefits, OFSP has to compete for space and position within the domain defined by the attributes of consumers and the foodstuffs they consume. A major moderator for this process is the acceptance of the OFSP by key decision makers. However, a dearth of knowledge exists regarding key decision makers' considerations for the acceptance of OFSP. In the extant literature, studies tend to be descriptive and focus on technology awareness and the channels for effective delivery of planting materials (e.g. Lukonge et al., 2015). Other related studies (e.g. Oparinde et al., 2014), are concerned with consumer willingness to pay for or consume bio-fortified staples, which approaches are not particularly helpful in assessing bio-fortification strategy given that rural households mainly grow their own food. Valuable insights may thus be gained by focusing on decision making by household members regarding uptake of bio-fortified staples. This paper discusses the extent to which decisionmakers' beliefs about OFSP and their valuation of the status of relationships they enjoy with actors they deem important influence their acceptance of OFSP. It also explores the role of decision-makers' desire for social approval and self-perceived capability as mediators of OFSP acceptance.

The theory of planned behaviour (TPB) and stages of change (SoC) model are psychosocial explanations of health-related behavioural change. Icek Ajzen initially advanced the TBP in 1991 positing that behavioural decisions (such as acceptance of OFSP) are not made spontaneously, but rather are a result of reasoned processes that are predicated by the decision maker's intention to engage in the specified behaviour (Ajzen, 2015). Under the TPB, behavioural intention is regarded as an intermediate output founded on the decision-makers' beliefs about whether important people approve or disapprove of the behaviour (subjective norms), overall positive or negative evaluation of the behaviour (attitude) and level of perceived control over performing a behaviour (perceived behavioural control).

The SoC models behavioural change as a five-stage process involving precontemplation, contemplation, preparation, action, and maintenance (Prochaska et al., 
Creative Commons User License: CC BY-NC-ND

Abstracted by: EBSCOhost, Electronic Journals Service (EJS),

Google Scholar, Journal Seek, Scientific Commons,

Food and Agricultural Organization (FAO), CABI and Scopus

http://eoi.citefactor.org/10.11226/v23i4
Journal of Agricultural Extension

Vol. 24 (1) January, 2020

ISSN(e): 24086851; ISSN(Print); 1119944X

http://journal.aesonnigeria.org

http://www.ajol.info/index.php/jae

Email: editorinchief@aesonnigeria.org

2013). Pre-contemplation and contemplation can be deemed to feed "behavioural intention" as described in the TPB, whereas preparation and action relate to "trial" activities, in which one experiments with the new behaviour, before deciding to maintain it (Prochaska et al.,2013).

This study combined TPB and SoC on the premise that the acceptance of OFSP by households is guided by a psycho-social process that integrates main decision makers' cost-benefit calculations and their desire not to compromise their status in the social groupings they subscribe to. The two models were deemed compatible since considerations of social approval and perceived capabilities as envisaged under the TPB can arguably feed the calculations that influence decisions to transition between the SoC stages. Besides, because an individual mentally applies a new idea to his or her present or likely future state before deciding whether or not to try it, intention could be considered as the first point of SoC.

The study adopted a SoC-based dependent variable, acceptance. Additionally, elements of TPB were used to generate indicators of the decision-makers' perceptions about their capability to pursue the opportunities nested in OFSP and their predisposition to adopt VAD alleviating variety in the face of social pressures to stick with conventional sweet potato varieties. The study tested the hypothesis that acceptance of OFSP among smallholder farmers in Uganda is a distal dependent variable that is significantly determined by household socio-demographic characteristics (Figure 1). It also tested the hypotheses that the influence of socio-demographic attributes on acceptance is significantly mediated by two key decision-makers' sociocognitive considerations; approval of their behaviour by significant others $(\mathrm{H} 1)$ and their own calculus of their capability to take up the technology (H2). 
Creative Commons User License: CC BY-NC-ND

Abstracted by: EBSCOhost, Electronic Journals Service (EJS),

Google Scholar, Journal Seek, Scientific Commons,

Food and Agricultural Organization (FAO), CABI and Scopus

http://eoi.citefactor.org/10.11226/v23i4
Journal of Agricultural Extension

Vol. 24 (1) January, 2020

ISSN(e): 24086851; ISSN(Print); $1119944 X$

http://journal.aesonnigeria.org

http://www.ajol.info/index.php/jae

Email: editorinchief@aesonnigeria.org

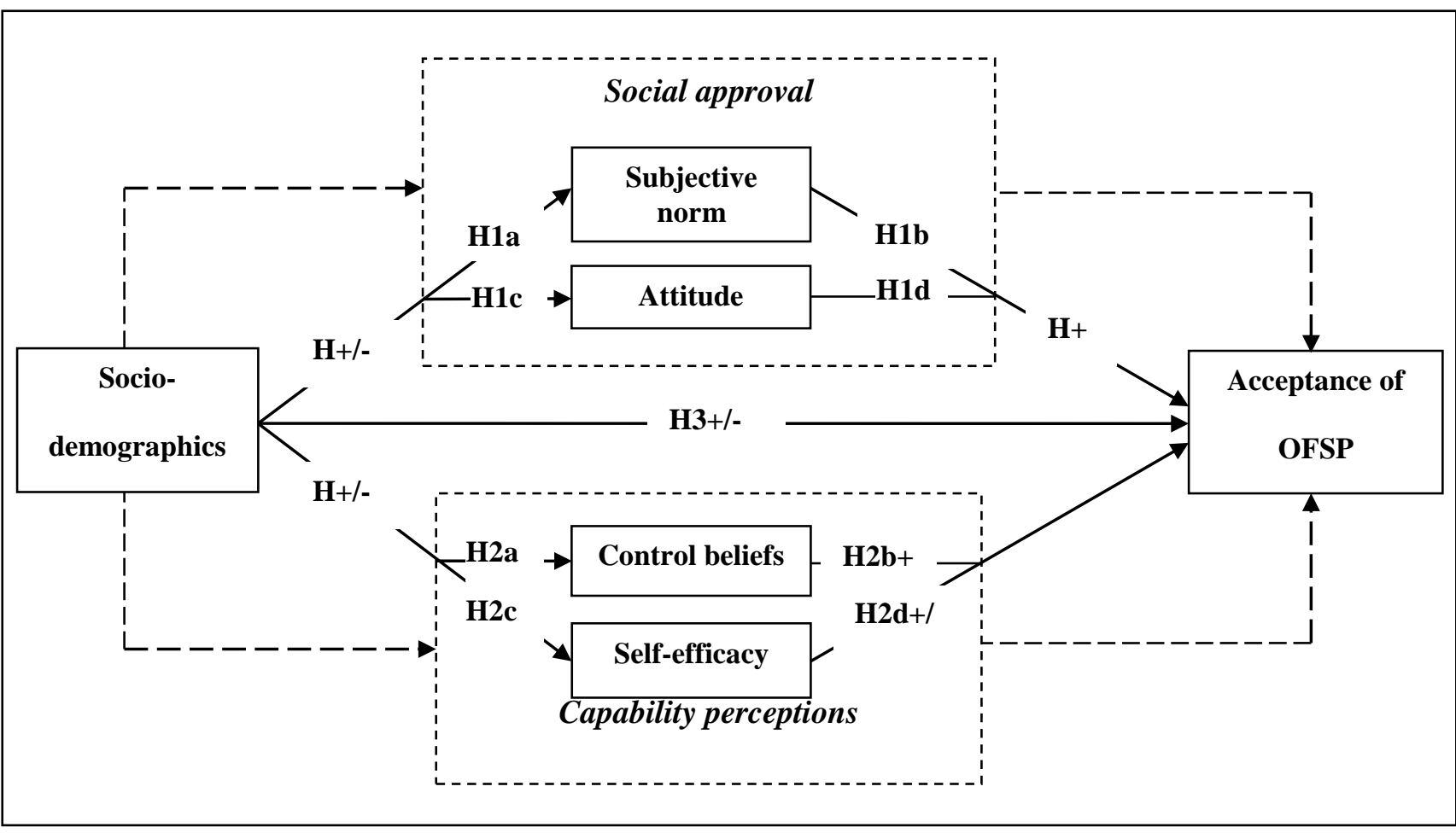

Figure 1: Acceptance of OFSP among smallholder farmers is determined by household socio-demographic characteristics

\section{Methodology}

This study was conducted in Uganda, a country that lies at $1^{0} 29^{\prime}$ South and $4^{0} 12^{\prime}$ North of the Equator and $29^{\circ} 34^{\prime}$ East and $35^{\circ} 0^{\prime}$ East of the Greenwich, in locations where production and consumption of OFSP was being promoted by a not-for-profit, non-governmental organization, HarvestPlus. HarvestPlus promotes agriculture for nutrition and health in developing countries (HarvestPlus, 2016). The study explicitly focused on the beneficiaries of the Developing and Delivering Bio-fortified Crops (DDBC) project, who included 409,711 households reached by the project between 2012 and 2016 in Uganda.

The DDBC project was implemented in Uganda with the aim of promoting widespread use of OFSP. By 2013, four regions comprising thirteen districts had been covered by the project. Two of the regions, central and eastern Uganda, were purposively selected using data on national VAD incidence (Uganda Bureau of Statistics (UBOS) and ICF International Inc, 2012). Central and eastern Uganda were respectively at the lower and higher ends of the VAD incidence continuum. Kirumba sub-county in Kyotera district 
Creative Commons User License: CC BY-NC-ND

Abstracted by: EBSCOhost, Electronic Journals Service (EJS),

Google Scholar, Journal Seek, Scientific Commons,

Food and Agricultural Organization (FAO), CABI and Scopus

http://eoi.citefactor.org/10.11226/v23i4
Journal of Agricultural Extension

Vol. 24 (1) January, 2020

ISSN(e): 24086851; ISSN(Print); 1119944X

http://journal.aesonnigeria.org

http://www.ajol.info/index.php/jae

Email: editorinchief@aesonnigeria.org

(central) and Bugaya in Buyende district (eastern) were randomly selected to represent the two study regions. The populations of the two sub counties are primarily rural and mostly subsist on rain-fed production of beans, maize, and white fleshed sweet potato (UBOS, 2016). One hundred households were randomly sampled from each of the selected sub-counties from the register of OFSP distribution contact groups, in order to arrive at a fairly large and equal sample size of study participants from either region. The two main decision-makers (female and male) were subsequently selected from each household for the individual interviews, resulting into a sample size of 400 participants.

Data were collected from 341 respondents (85\% response rate consisting of $55 \%$ female and 45\% male) in April and May 2017 using a 29 item seven-point Likert scale (1 = not-like me, 7 = more-like me) questionnaire. The items captured four hypothesized mediating variables: control beliefs (10 items), self-efficacy (10 items), subjective norm (4 items) and attitude (5 items). The scale items were adapted from Ajzen (2013) and Mackie et al (2015). Socio-demographic data (VAD experience, income and education level) were also gathered about the respondents. VAD experience was captured using a binary scale (no = 1 and yes $=2$ ). Income, which was measured on a metric scale, was later collapsed into four equal interval categories. Formal education attainment categories were collapsed into four (none $=1$, primary $=2$, secondary $=3$, and postsecondary $=4)$ to cater for those which only had a few responses. The dependent variable was measured basing on a three-point Likert-type scale ( $1=$ under consideration, 2 = trial action and 3 = maintenance) adapted from Prochaska et al. (2013).

The questionnaire was pretested on 16 households in Nsambya village, Rakai district, which was selected because of its distant location from the study sub-counties (60 kilometres for sites in Kyotera and 420 kilometres for Buyende) to avoid contaminating the main sample. Following the Cronbach's alpha reliability analysis, and in line with Taber (2018), only items with coefficients greater than .70 were used for subsequent data collection. The coefficients for control beliefs, self-efficacy, subjective norm and attitude were $.85, .90, .71$ and .84 respectively, indicating that the scales used to measure the study constructs had a generally strong internal consistency and reliability. Given that respondents lived in areas with known high illiteracy rates (UBOS, 2016), the instrument was administered by trained interviewers in native languages. Prior to data collection, written permission to engage project beneficiaries as study participants was obtained from HarvestPlus. Before each interview, participants were informed of their rights, the study purpose and were also assured of confidentiality. Each participant also signed a consent letter.

Data analysis was done in three steps. First, principal component analysis (PCA) was done. The Kaiser-Meyer-Olkin (KMO) test of sampling adequacy and Bartlett's test of sphericity, with Eigen values set at 1 was performed to reduce the number of items into 
Creative Commons User License: CC BY-NC-ND

Abstracted by: EBSCOhost, Electronic Journals Service (EJS),

Google Scholar, Journal Seek, Scientific Commons,

Food and Agricultural Organization (FAO), CABI and Scopus

http://eoi.citefactor.org/10.11226/v23i4
Journal of Agricultural Extension

Vol. 24 (1) January, 2020

ISSN(e): 24086851; ISSN(Print); 1119944X

http://journal.aesonnigeria.org

http://www.ajol.info/index.php/jae

Email: editorinchief@aesonnigeria.org

a parsimonious dataset as suggested by Field (2013). Second, descriptive statistics and bivariate correlations were computed to describe the variables and appraise conceptual relationships. Third, hierarchical regression was performed with SPSS version 16 (using 'enter method') to determine the major predictors of OFSP acceptance. Mediation effects were determined using the three criteria commonly used in psychosocial studies, since they were first suggested by Baron and Kenny three decades ago. Baron and Kenny posit that mediation is said to be established if (i) variations in levels of the independent variable significantly account for variations in the presumed mediator (Path a), (ii) variations in the mediator significantly account for variations in the dependent variable (Path b), and (iii) when Paths $a$ and $b$ are controlled, a previously significant relation between the independent and dependent variables (Path $c$ ) is no longer significant (Lemmens, et al., 2016). In a proper mediation, the correlation between independent and dependent variable need not be significant.

\section{Results and Discussion}

\section{Descriptive statistics for the socio-demographics and acceptance of OFSP}

The socio-demographic factors examined were the decision-makers' VAD experience, educational attainment and average monthly income. Two of every three decisionmakers $(67 \%)$ did not consider VAD a major problem in their households while $56 \%$ did not consider it a major problem for the community. A plausible explanation for the discrepancy, as suggested by Ndaula et al. (2019), is that the communities are not sufficiently sensitized about VAD to be able to associate patient symptoms with their VAD status. The decision-makers may also have under-reported VAD prevalence in their households because it is socially more acceptable to do so. Consistent with the national census (UBOS, 2016), 66\% of the respondents in this study had only attained some level of primary education, $21 \%$ had attained secondary education, $6 \%$ had attained tertiary education while $7 \%$ had not had any formal education. Most of the respondent households (71\%) earned US\$ 3 or less per month; only $28 \%$ earned above US\$ 3, implying that virtually all the households lived in extreme poverty (World Bank, 2016).

Regarding acceptance of OFSP, $70 \%$ of the households had maintained OFSP cultivation for more than six months, $19 \%$ were carrying out trial cultivation while $11 \%$ were still considering starting to cultivate OFSP varieties. It is also noteworthy that most of the households at the maintenance stage had OFSP covering less than $20 \%$ of the acreage under sweet potato.

\section{Capability Perceptions and Social Approval}

The PCA revealed three factors as underlying control beliefs (Table 1). Perceived household control over timeliness of labour, general labour, financial resources outside the household and financial resources within the household loaded highly (factor loadings over .7) against Component 1. Perceived household control over the fertility of 
Creative Commons User License: CC BY-NC-ND

Abstracted by: EBSCOhost, Electronic Journals Service (EJS),

Google Scholar, Journal Seek, Scientific Commons,

Food and Agricultural Organization (FAO), CABI and Scopus

http://eoi.citefactor.org/10.11226/v23i4
Journal of Agricultural Extension

Vol. 24 (1) January, 2020

ISSN(e): 24086851; ISSN(Print); 1119944X

http://journal.aesonnigeria.org

http://www.ajol.info/index.php/jae

Email: editorinchief@aesonnigeria.org

soils and adequacy of soil water loaded highly (factor loadings over .8) against Component 2. Perceived control over other farmers growing OFSP and access to OFSP vines loaded highly (factor loadings over .8) against Component 3 . In line with Field (2013)'s suggestion that an extracted component is primarily a measure of the factor with which it is most strongly correlated, the components were labelled as control belief (access to labour), control belief (soil fertility) and control belief (vine access). Selfefficacy and subjective norms and attitudes in social approval domain had only one factor each extracted, thus all retained their original variable labels.

KMO measure of sampling adequacy obtained for the extracted factors were equal to or higher than the recommended .5 and the Bartlett's test of sphericity were also significant ( $p \leq .001)$ (Table 2). Eigenvalues were above Kaiser's criterion of 1 and the factors explained $66.5 \%, 52.4 \%, 54 \%$ and $61 \%$ of the variance in data of control belief, self-efficacy, subjective norm and attitude respectively; it was thus acceptable to proceed with the analysis (Field, 2013).

Bivariate correlation of the study variables showed that five variables: education, VAD experience, average monthly income, subjective norms, and control beliefs (vine access) were significant predictors of acceptance of OFSP $(p \leq .01)$ (Table 3). Attitude, self-efficacy and control belief (access to labour), and control belief (soil fertility) were not. Among the independent variables, self-efficacy was outstanding in being correlated $(p \leq .01)$ to all the other variables except education. These relationships imply that selfefficacy is probably mediated by other variables given that it does not significantly associate with acceptance.

\section{Table 1: Rotated factor loadings underlying control belief}

\begin{tabular}{lccc}
\hline \multirow{2}{*}{ Control belief items about } & \multicolumn{3}{c}{ Rotated factor loadings } \\
\cline { 2 - 4 } & $\begin{array}{c}\text { Control belief } \\
\text { (access to labour) }\end{array}$ & $\begin{array}{c}\text { Control belief (soil } \\
\text { fertility) }\end{array}$ & $\begin{array}{c}\text { Control belief (vine } \\
\text { access) }\end{array}$ \\
\hline Timely labour & .807 & & \\
General labour & .792 & & \\
Financial resource outside & .781 & & \\
household & & & \\
Financial resource within household & .744 & .881 & .866 \\
OFSP to experts/ trainers & .542 & .825 & .820 \\
Fertile soils & & & .564 \\
Adequate soil water & .494 & & \\
Land for OFSP growing & & & \\
Other farmers growing OFSP & & & \\
OFSP vines & & & \\
\hline Extracted using Principal Compons
\end{tabular}

Extracted using Principal Component Analysis. Rotation converged in 5 iterations. 
Creative Commons User License: CC BY-NC-ND

Abstracted by: EBSCOhost, Electronic Journals Service (EJS),

Google Scholar, Journal Seek, Scientific Commons,

Food and Agricultural Organization (FAO), CABI and Scopus

http://eoi.citefactor.org/10.11226/v23i4
Journal of Agricultural Extension

Vol. 24 (1) January, 2020

ISSN(e): 24086851; ISSN(Print); 1119944X

http://journal.aesonnigeria.org

http://www.ajol.info/index.php/jae

Email: editorinchief@aesonnigeria.org

Table 2: Summary of explanatory factors

\begin{tabular}{|c|c|c|c|c|c|c|c|}
\hline Factors & $\begin{array}{l}\text { Number } \\
\text { of items }\end{array}$ & $\begin{array}{l}\text { Mean } \\
\text { score }\end{array}$ & Variance & $\begin{array}{c}\text { Bartlett's } \\
\text { test }\end{array}$ & $\mathrm{KMO}$ & Eigenvalue & $\begin{array}{l}\text { \% Variance } \\
\text { explained }\end{array}$ \\
\hline $\begin{array}{l}\text { Experience with } \\
\text { VAD }\end{array}$ & 2 & 1.4 & .025 & $49.0^{* * *}$ & .500 & 1.37 & 68.4 \\
\hline Subjective norms & 4 & 3.2 & .393 & $342^{* * *}$ & .493 & 2.16 & 54.0 \\
\hline Attitudes & 5 & 5.1 & .019 & $639^{\star * *}$ & .823 & 3.05 & 61.0 \\
\hline Control beliefs & 10 & 2.8 & .214 & $1375^{\star \star *}$ & .802 & 1.08 & 66.5 \\
\hline $\begin{array}{l}\text { Control } \\
\text { belief(labour) }\end{array}$ & 5 & - & & - & & 4.30 & 31.0 \\
\hline $\begin{array}{l}\text { Control belief (soil } \\
\text { fertility) }\end{array}$ & 3 & - & & - & & 1.28 & 19.8 \\
\hline $\begin{array}{l}\text { Control belief (vine } \\
\text { access) }\end{array}$ & 2 & - & & - & & 1.08 & 15.7 \\
\hline Self-efficacy & 10 & 3.1 & .014 & $1611^{\star \star *}$ & .907 & 5.24 & 52.4 \\
\hline
\end{tabular}

Table 3: Correlation matrix for study variables

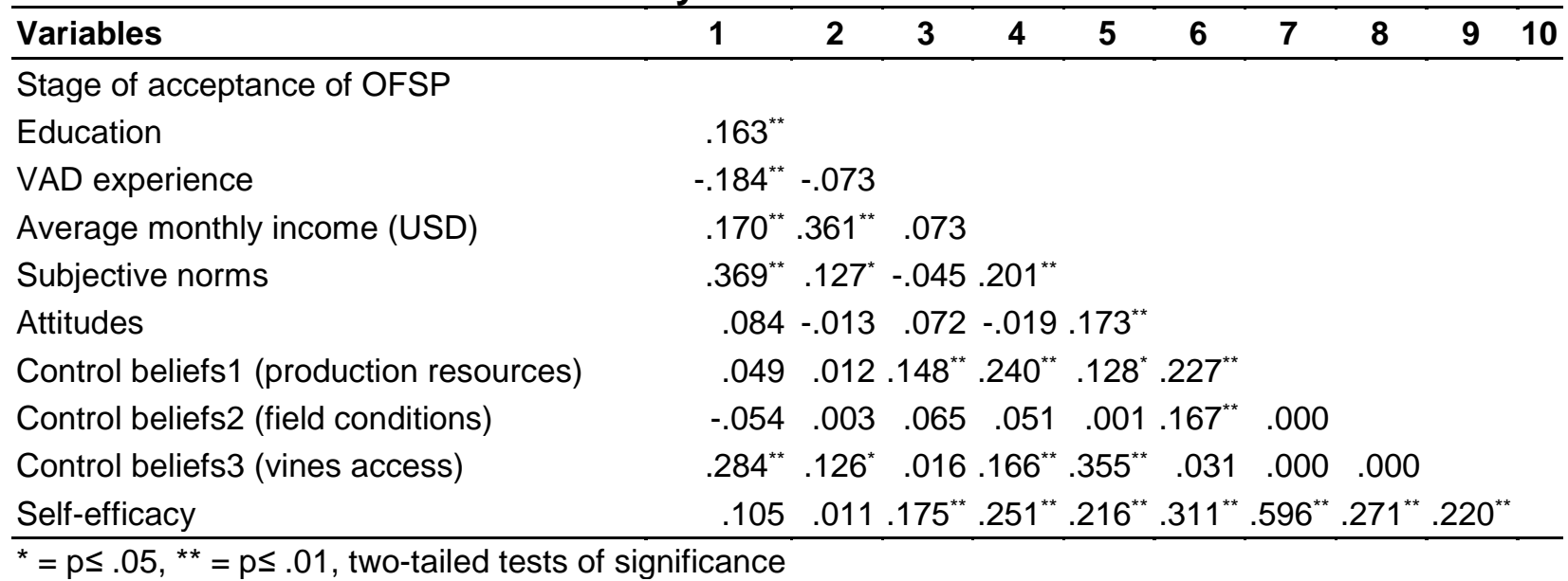

\section{Effect of Socio-Demographics and Socio-Cognitive Factors on Acceptance}

Table 4 shows the hierarchical regression analyses conducted to test the influence of the three main predictors of acceptance, hypothesised earlier in this paper (Figure 1).

Models 1-4 tested the relationships between independent and mediator variables in $\mathrm{H} 1 \mathrm{a}$ and $\mathrm{c}$ and $\mathrm{H} 2$ a and $\mathrm{c}$. The first hypothesis proposed that socio-demographics are related to subjective norm ( $\mathrm{H} 1 \mathrm{a})$ and as shown in the first model, the hypothesis was supported $\left(R^{2}=.046, F=5.4, p \leq .01\right)$. The second hypothesis stated that sociodemographics are related to attitudes $(\mathrm{H} 1 \mathrm{c})$. As shown in the second model this 
Creative Commons User License: CC BY-NC-ND

Abstracted by: EBSCOhost, Electronic Journals Service (EJS),

Google Scholar, Journal Seek, Scientific Commons,

Food and Agricultural Organization (FAO), CABI and Scopus

http://eoi.citefactor.org/10.11226/v23i4
Journal of Agricultural Extension

Vol. 24 (1) January, 2020

ISSN(e): 24086851; ISSN(Print); 1119944X

http://journal.aesonnigeria.org

http://www.ajol.info/index.php/jae

Email: editorinchief@aesonnigeria.org

hypothesis was not supported. This implies that socio-demographics were not significant predictors of positive or negative attitudes towards OFSP among decisionmakers in the study. Further, the third hypothesis which stated that socio-demographics influence perceived control $(\mathrm{H} 2 \mathrm{a})$, was supported as indicated by the third model $\left(\mathrm{R}^{2}=\right.$ $.032, \mathrm{~F}=3.7, p \leq .05)$. Lastly, the fourth hypothesis which asserted that sociodemographics influence self-efficacy $(\mathrm{H} 2 \mathrm{c})$ was supported as suggested by the fourth model $\left(R^{2}=.093, F=11.4, p \leq .001\right)$. Thus, this study established that $\mathrm{H} 1 \mathrm{a}, \mathrm{H} 2 \mathrm{a}$ and $\mathrm{H} 2 \mathrm{c}$ met the first criterion for establishing mediation namely, that variations in levels of the independent variable significantly account for variations in the presumed mediator. This is consistent with psychosocial studies (e.g. Rivera and Pérez, 2015) that indicate that the context in which a decision maker operates is important in the formation of the latent beliefs on which most salient psychosocial variables, such as self-efficacy, depend.

Table 4: Hierarchical regression results for mediators and acceptance of OFSP

\begin{tabular}{|c|c|c|c|c|c|c|c|}
\hline \multicolumn{8}{|c|}{ Decision-makers $(n=340)$} \\
\hline \multirow[t]{2}{*}{ Variables } & \multicolumn{4}{|c|}{ Mediators $^{a}$} & \multicolumn{2}{|c|}{ Acceptance } & \multirow{2}{*}{$\begin{array}{l}\text { of } \\
\text { VIF }\end{array}$} \\
\hline & $\begin{array}{c}\text { Model } \\
\beta 1\end{array}$ & $\begin{array}{c}\text { Model } \\
\boldsymbol{\beta 2}\end{array}$ & $\begin{array}{c}\text { Model } \\
\boldsymbol{\beta 3}\end{array}$ & $\begin{array}{c}\text { Model } \\
\boldsymbol{\beta} 4\end{array}$ & $\begin{array}{l}\text { Model } \\
\text { B5 }\end{array}$ & $\begin{array}{c}\text { Model } \\
\beta 6\end{array}$ & \\
\hline \multicolumn{8}{|l|}{ Independent variables } \\
\hline Education & .083 & .002 & .114 & -.110 & .097 & .069 & 1.180 \\
\hline VAD experience & -.055 & .074 & .012 & $.150^{\star *}$ & $-.129^{\star \star \star}$ & $-.124^{\star \star \star}$ & 1.051 \\
\hline Av. monthly income (US\$) & $.139^{* *}$ & -.017 & $.103^{*}$ & $.202^{\star \star *}$ & $.076^{*}$ & .039 & 1.280 \\
\hline \multicolumn{8}{|l|}{ Mediator variables } \\
\hline Subjective norm & & & & & & $.182^{* * *}$ & 1.228 \\
\hline Attitude & & & & & & .036 & 1.148 \\
\hline $\begin{array}{l}\text { Control beliefs vine } \\
\text { access }\end{array}$ & & & & & & $.114^{\star *}$ & 1.190 \\
\hline Self-efficacy (SE) & & & & & & .007 & 1.285 \\
\hline $\mathrm{R}^{2}$ & .046 & .006 & .032 & .093 & .074 & .206 & \\
\hline Adjusted $\mathrm{R}^{2}$ & .038 & -.003 & .024 & .085 & .066 & .189 & \\
\hline $\mathrm{F}$ & $5.4^{\star \star}$ & .638 & $3.7^{*}$ & $11.4^{* \star *}$ & $9.0^{* * *}$ & $12.3^{* \star \star}$ & \\
\hline
\end{tabular}

Model 6 was used to test four hypotheses ( $\mathrm{H} 1 \mathrm{~b}$ and $\mathrm{d}$ and $\mathrm{H} 2 \mathrm{~b}$ and $\mathrm{d}$ ), which focused on the relationships between the independent, mediator and dependent variables. Overall, this model was supported by the data $\left(\mathrm{R}^{2}=.206, \mathrm{~F}=12.3, p \leq .001\right)$. Specifically, the hypothesis that stated that subjective norms positively influence acceptance of OFSP $(\mathrm{H} 1 \mathrm{~b})$ was supported $(\beta=0.182, P \leq .001)$. However, $\mathrm{H} 1 \mathrm{~d}$ that stated that attitude positively relates with acceptance of OFSP was not supported. Accordingly, Model 6 met the second criterion for establishing mediation, namely that variations in the mediator significantly account for variations in the dependent variable. Thus, subjective norms significantly predicted acceptance of OFSP, but attitude did not. These findings 
Creative Commons User License: CC BY-NC-ND

Abstracted by: EBSCOhost, Electronic Journals Service (EJS),

Google Scholar, Journal Seek, Scientific Commons,

Food and Agricultural Organization (FAO), CABI and Scopus

http://eoi.citefactor.org/10.11226/v23i4
Journal of Agricultural Extension

Vol. 24 (1) January, 2020

ISSN(e): 24086851; ISSN(Print); 1119944X

http://journal.aesonnigeria.org

http://www.ajol.info/index.php/jae

Email: editorinchief@aesonnigeria.org

conform with those of social norm studies and the norm descriptive narrative (e.g., Mackie et al., 2015; Cislaghi and Heise, 2018)), which established that changing a socially embedded behaviour requires a critical mass of community members to believe that enough near-peers are accepting or expect them to accept the novel behaviour; otherwise, attitude becomes an inadequate predictor. Arguably one cannot have tenacious attitudes about ideas that he/she has not fully experienced; hence before an adopter tries out a technology, the attitude he or she holds is likely to be an outcome of external influence and unaligned with their behaviour.

The hypothesis that stated that perceived control positively relates with acceptance of OFSP (H2b) was supported $(\beta=0.114, P \leq .01)$. The status of the relationship between control belief and acceptance of OFSP conforms with the findings of previous studies that used TBP concepts (e.g. Talsma et al., 2013). Talsma et al. (2013) found control beliefs to be a vital predictor for caregivers' intentions to feed children on orangefleshed cassava in Uganda. This highlights control over production inputs required by households to cultivate OFSP as a core element of a household's calculations in deciding whether to accept or reject the technology.

Insignificant evidence was found regarding the association between self-efficacy and acceptance of OFSP. Accordingly, $\mathrm{H} 2 \mathrm{~d}$ did not meet the second criterion for establishing mediation. Vancouver and Purl (2017) assert that self-efficacy is clearly positively affected by past performance, implying that its effect on behaviour can be negative, unrelated, or positive. By extension of this logic, self-efficacy may not have effectively predicated OFSP acceptance in this study because self-efficacy beliefs about the OFSP were probably confounded by experience with sweet potato varieties previously grown by the respondent households. Nezami et al. (2016) also reported that the ability of self-efficacy in explaining behavioural changes may be limited by lack of activity specificity to which self-efficacy is referenced. In this study, self-efficacy was measured following the sweet potato value chain activities (from site selection to cooking), which was presumed sufficient to eliminate the measurement effect.

Model 5 tested the relationship between the independent and dependent variables in $\mathrm{H} 3$ hypothesis that stated that socio-demographics had a significant direct influence on acceptance of OFSP $\left(R^{2}=.074, F=9.0, p \leq .001\right)$. Accordingly, $\mathrm{H} 3$ did not meet the third criterion for establishing mediation, namely that "when paths $a$ and $b$ are controlled, $a$ previously significant relation between the independent and dependent variables is no longer significant, with the strongest demonstration of mediation occurring when Path $c$ is zero". This implies that even after controlling for subjective norm and perceived control, both of which met the first and second criteria for establishing mediation, a significant $7.4 \%$ of the variance in household acceptance of OFSP probably continued to be accounted for by mediators currently not included in the study's conceptual model. The study revealed subjective norms (in social approval domain) and control beliefs (in the capability perceptions domain) to significantly mediate the acceptance of OFSP, 
Creative Commons User License: CC BY-NC-ND

Abstracted by: EBSCOhost, Electronic Journals Service (EJS),

Google Scholar, Journal Seek, Scientific Commons,

Food and Agricultural Organization (FAO), CABI and Scopus

http://eoi.citefactor.org/10.11226/v23i4
Journal of Agricultural Extension

Vol. 24 (1) January, 2020

ISSN(e): 24086851; ISSN(Print); 1119944X

http://journal.aesonnigeria.org

http://www.ajol.info/index.php/jae

Email: editorinchief@aesonnigeria.org

since almost all coefficients of the socio-demographic variables (model 5) reduced and became insignificant, on introducing in the mediator variables in the model. Only the coefficients of farmers' experience with VAD remained constant and significantly related with acceptance, implying that this relationship could be mediated by some other variables.

\section{Conclusion and Recommendations}

subjective norms in the social domain and control beliefs under capability perceptions were associated with acceptance of OFSP. These results point to a cardinal role for processes that create supportive social and cognitive environments for promoting biofortified technologies, such as orange fleshed sweet potato. The results further suggest that beyond individual decisions that household level decision makers make, it is vital to seek to alter the perceptions held by the near-peers especially those actually cultivating OFSP and have the capacity to be leaned on by peers to do the same. This could be achieved for example through variety endorsements (e.g. by leaders and pop stars), or through targeting the most motivated and connected members of the community first, when designing OFSP dissemination campaigns. Similarly, farmer groups could be strengthened to better support members to grow OFSP. The results also point to the need to train farmers, particularly in activities such as vine preservation and production sequencing between seasons that increase access to OFSP planting materials.

The study also established that socio-demographic characteristics strengthen both subjective norms and control beliefs which in turn increase OFSP acceptance; both mediated effects are positive. The direct effect of socio-demographic characteristics was also positive. Consequently, a state of complementary mediation pertains. However, the presence of a significant direct effect of socio-demographic characteristics on acceptance, points to a need for future research to explore the possibility of additional mediators. In particular, the positive direction of the effect hints at probable addition mediator(s) whose effect is likely to be positive.

\section{Acknowledgement}

We are grateful to DAAD-RUFORUM in-country scholarship for funding data collection for this study. The manuscript was prepared at the University of Nairobi with funding from the European Union-funded IntraACP ARISE mobility scholarship.

\section{Reference}

Ajzen, I. (2013). Theory of planned behaviour questionnaire. Measurement instrument database for the social science. Retrieved from www.midss.ie.

Ajzen, I. (2015). The theory of planned behaviour is alive and well, and not ready to retire: a commentary on Sniehotta, Presseau, and Araújo-Soares. Health Psychol Revi., 9(2): 13117.

Asare-marfo, D., Gonzalez, C., Perez, S., Schwarz, J., \& Zeller, M. (2013). Prioritizing countries for biofortification interventions using country-level data, Washington DC, (HarvestPlus Working paper No. 11). 
Creative Commons User License: CC BY-NC-ND

Abstracted by: EBSCOhost, Electronic Journals Service (EJS),

Google Scholar, Journal Seek, Scientific Commons,

Food and Agricultural Organization (FAO), CABI and Scopus

http://eoi.citefactor.org/10.11226/v23i4
Journal of Agricultural Extension

Vol. 24 (1) January, 2020

ISSN(e): 24086851; ISSN(Print); 1119944X

http://journal.aesonnigeria.org

http://www.ajol.info/index.php/jae

Email: editorinchief@aesonnigeria.org

Cislaghi, B., \& Heise, L. (2018). Theory and practice of social norms interventions: Eight common pitfalls. Globalization and Health, 14(83): 1-10.

Field, A. (2013). Discovering statistics using IBM SPSS statistics. (M. Carmichael, R. Lupton, T. Shukla, I. Antchliff, andR. Laigh, Eds.) (4th edition). SAGE.

HarvestPlus. (2016). Driving impact: annual report 2016. Washington DC, USA.

Lemmens, L. J. M., Muller, V. N. L. S., Arntz, A., \& Huibers, M. J. H. (2016). Mechanisms of change in psychotherapy for depression: An empirical update and evaluation of research aimed at identifying psychological mediators. Clin Psychol Rev, 50:95-107.

Low, J. W., Mwanga, R. O. M., Andrade, M., Carey, E., \& Ball, A. M. (2017). Tackling vitamin A deficiency with biofortified sweetpotato in sub-Saharan Africa. Global Food Secur., 14(January): 23-30.

Lukonge, E. J., Gibson, R. W., Laizer, L., Amour, R., \& Phillips, D. P. (2015). Delivering new technologies to the Tanzanian sweetpotato crop through its informal seed system. Agroecol. Sust. Food., 39(8):1-33.

Mackie, G., Moneti, F., Shakya, H. \& Denny, E. (2015). What are social norms? How are they measured? San Diego, USA.

Ndaula, S., Matsiko, F., \& Sseguya, H. (2019). Farmers' multidimensional beliefs in orangefleshed sweetpotato acceptance among rural households in Uganda 1. Advances in Agricultural Science, 7(02), 100-112.

Nezami, B. T., Jakicic, J. M., Davis, K. K., Polzien, K., Rickman, A. D., Hatley, K. E. \& Tate, D. F. (2016). The effect of self-efficacy on behavior and weight in a behavioral weight-loss intervention. Health Psychol., 35(7): 714-722.

Oparinde, A., Banerji, A., Birol, E., \& Ilona, P. (2014). Information and consumer willingness to pay for biofortified yellow cassava: evidence from experimental auctions in Nigeria Washington DC.(HarverstPlus Working Paper No. 13).

Prochaska, J. O., Norcross, J. C., \& DiClemente, C. C. (2013). Applying the stages of change. Psychotherapy in Australia, 19(2):10-15.

Rivera, C. E., \& Pérez, C. C. (2015). Influence of contextual factors on EFL Mexican teachers' beliefs and the use of textbooks. HOW, 22(2): 75-90.

Taber, K. S. (2018). The Use of Cronbach's Alpha When Developing and Reporting Research Instruments in Science Education. Res Sci Edu.,48(6): 1273-1296.

Talsma, E. F., Melse-boonstra, A., Kok, B. P. H. De, Mbera, G. N. K., Mwangi, A. M. \& Brouwer, I. D. (2013). Biofortified cassava with pro-vitamin A is sensory and culturally acceptable for consumption by primary school children in Kenya. PLoS ONE, 8(9): e73433-e73433.

Uganda Bureau of Statistics. (2016). The National Population and Housing Census 2014 - Main Report. Kampala.

Uganda Bureau of Statistics and ICF International Inc. (2012). Uganda Demograpic and Health Survey 2011. Kampala; Uganda.

Vancouver, J. B. \& Purl, J. D. (2017). A computational model of self-efficacy's various effects on performance: Moving the debate forward. J. Appl. Psychol., 102(4): 599-616.

Wirth, J. P., Petry, N., Tanumihardjo, S. A., Rogers, L. M., McLean, E., Greig, A., ... Rohner, F. (2017). Vitamin a supplementation programs and country-level evidence of vitamin $A$ deficiency. Nutrients, 9(190):1-18.

World Bank. (2016). The Uganda Poverty Assessment Report 2016: Farms, cities and good fortune: assessing poverty reduction in Uganda from 2006 to 2013. Washington DC. 